\title{
ARTICLES
}

\section{Historic or Historical? Lost in Translation of "li shi xing quan li" in the South China Sea Arbitration}

\author{
Ran Guo*
}

In the South China Sea Arbitration, the Chinese term- "li shi xing quan li" was mistranslated into "historic rights short of title," regardless of the official English translation provided by Chinese government and preserved by international organizations. 'quan li' connotes a categorical meaning covering sovereignty and non-sovereignty rights, while "li shi xing" relates to claims and conduct historically before 1982. China's "Ii shi xing quan li" in the SCS developed with the history of the general category of historic rights-an umbrella concept connoting both exclusive historic title and non-exclusive historic sovereign rights. It included China's exclusive sovereignty over nansha qundao in the SCS and its non-exclusive sovereign rights in part of SCS. The Arbitral Tribunal's negligence of the conceptual difference led to uncertainty in China's maximum maritime entitlements in the SCS and reasonable doubt about its decision on the Philippines' Submissions 1 and 2.

\section{Keywords}

li shi xing quan li, Historic Rights, South China Sea Arbitration, China's EEZ/CS ACt, UNCLOS

* Associate professor at East China Normal University. B.A. (Henan Normal Univ.), M.A. (Tianjin Foreign Studies Univ.), Ph.D. (Wuhan). He was a Visiting Fellow (2016-17) at Lauterpacht Centre for International Law and Wolfson College, Cambridge, UK, and a Fulbright Visiting Scholar (2007-08) at Hampden-Sydney College, US. ORCID: https://orcid.org/0000-0001-8450-6495. The viewpoints expressed in the article are the author's own and do not represent those of any institution or that of the Chinese government. The author may be contacted at: rguo@fl.ecnu. edu.cn / Address: School of Foreign Languages, East China Normal University, Shanghai, P.R. China 200062. 


\section{Introduction}

As international arbitration is a trans-cultural venture, any procedural deficiencies or false assessments of language issues can be determinative to the proceeding leading to an inefficient or even invalid arbitration. Therefore, one of the challenges for international arbitration is to bridge linguistic differences. ${ }^{1}$ The Philippines requested the Arbitral Tribunal constituted under Annex VII to the 1982 United Nations Conventions on the Law of the Sea ("UNCLOS") ${ }^{2}$ (hereinafter Tribunal) to adjudge China's claims to 'historic rights' in the South China Sea ("SCS"), ${ }^{3}$ which, the Philippines asserted, was the English translation of the Chinese term - "li shi xing quan li." However, the Tribunal was aware that "China has never expressly clarified the nature or scope of its claimed historic rights," so that it was unable to directly connect 'historic rights' with China's "li shi xing quan li." Hence, some questions are still pending as follows: What is the meaning of the Chinese term "li shi xing quan li'? Could it be appropriately translated as 'historic rights'? What should an international tribunal do with the translation and interpretation of a legal term in municipal law? Is it possible for an entire arbitration to become void due to a wrong translation of the key term giving rise to wrong subject-matter?

This research is to answer those questions and clarify the real meaning of "li shi xing quan li" in this context. This paper is composed of six parts including Introduction and Conclusion. Part II will look into the two versions of the English translation of the Chinese Term - "li shi xing quan li" and probe into the reasons for the mistranslation. Part III will investigate the translation of 'quan li' into "rights short of title," which was logically and literally wrong. Part IV will analyze the difference between "li shi xing" and 'historic' by taking a critical date test. Part V will trace the conceptual evolution of "li shi xing quan li" and 'historic rights,' comprising

1 S. Wilske, Linguistic and Language Issues in International Arbitration: Problems, Pitfalls and Paranoia, 9 Contemp. Asia Arb. J. 161 (2016).

2 UNCLOS, adopted on Dec. 10, 1982; entered into force on Nov. 16, 1994, 1833 U.N.T.S. 397.

3 The Philippines Memorial (vol. 1) (hereinafter Memorial), 9.157 (Submission 2), available at http://www. pca-cpa. org/pcadocs/Memorial\%20of\%20the\%20Philippines\%20Volume\%20I.pdf. The text and annexes of the Memorial as well as transcripts of the hearings contain all the information about the South China Sea Arbitration, available at https:// pcacases.com/web/view/7 (last visited on Apr. 30, 2018). For details, see M. Gau, The Sino-Philippine Arbitration on the South China Sea Disputes and the Taiwan Factor, 9 J. EAst AsIA \& InT'L L. 480-4 (2016).

4 The South China Sea Arbitration Award before An Arbitral Tribunal Constituted under Annex VII to the UNCLOS between the Philippines and P.R. China, Perm. Ct. Arb. (Case No. 2013-19) [hereinafter Award of July 12, 2016], - 180, available at https://pca-cpa.org/wp-content/uploads/sites/175/2016/07/PH-CN-20160712-Award.pdf (last visited on Apr. 30, 2018). [Emphasis added]. 
both historic title and historic sovereign right, in order to determine the limit of China's maximum entitlements in the SCS under the UNCLOS. The Tribunal's negligence of the conceptual difference led to uncertainty in China's maximum maritime entitlements in the SCS and reasonable doubt about its Award.

\section{Two Versions of the English Translation of the Chinese Term - "li shi xing quan li"}

\section{A. The Philippines' Translation}

How did the Philippines link 'historic rights" with China's "li shi xing quan li" from the very beginning ${ }^{6}$ The Philippines' Memorial asserted:

What is clear is that China claimed 'historical rights' as distinguished from 'historic title.' The Chinese text asserts China's 历史性权利 (li shi xing quan li), which corresponds to legal rights short of title. The Chinese word for title, by contrast, is 历史性所有权 (li shi xing suo you quan), which is the same word that appears in Article 15 of the Chinese text of UNCLOS as the counterpart of the English word 'title."

During the Jurisdiction Hearing, the Philippines further explained the concept of 'historic rights' and its link with China's "li shi xing quan li" in Article 14 of China's Exclusive Economic Zone and Continental Shelf Act (hereinafter China's EEZ/CS Act of 1998), ${ }^{8}$ the only reference to "li shi xing quan li" in China's municipal law. The Philippines told the Tribunal how it translated the phrase as follows:

In the Chinese text of Article 298(1) (a), the words for "historic titles" are li shi xing suo you quan; literally translated, "power of possession or ownership." In contrast, what China has repeatedly claimed beyond its entitlements under 1982 Convention, are $l i$

5 Memorial, ๆ 271.

6 For the convenience of this article, the Chinese term "li shi xing quan li" is used to indicate the general category of historic rights claimed by China, while the English term 'historic rights' is used to indicate the narrow 'historic rights' (the rights short of title) asserted by the Philippines.

7 Memorial, 9 甲 4.28 \& 7.133.

8 PRC Exclusive Economic Zone and Continental Shelf Act, adopted at the 3rd Meeting of the Standing Committee of the Ninth National People's Congress on June 26, 1998, available at http://www.npc.gov.cn/englishnpc/Law/200712/11/content_1383573.htm (last visited on Apr. 30, 2018). 
shi xing quan li, which are rights that do not amount to title or ownership. ${ }^{9}$

Apparently, the method employed by the Philippines to translate this Chinese legal term was a 'mechanical' word-for-word translation, which was not only a cause for mistranslation, ${ }^{10}$ but also contrary to international jurisprudence. In Kılıç v. Turkmenistan, the Tribunal declared: "Accurate translation of, for example, a sentence in one language into another, requires something more than a literal and word-for-word translation of each and every word employed in the text that is being translated."

As the Philippines did not provide any expert opinion on the translation or the meaning of "li shi xing quan li" to the Tribunal, none of its five arbitrators had any clue of the Chinese meaning of this term. Instead, the Philippines merely asserted that this was the translation. ${ }^{12}$ In the Philippines' translation, however, there were two obvious factual mistakes. First, "li shi xing suo you quan" could not be literally translated into "power of possession or ownership," because 'quan' (权) as a suffix is a short form for 'quan li' (权利), which means 'rights,' not 'quan li' (权力), which means 'power.' [Emphasis added]

Second, the translation of "li shi xing quan li" in China's EEZ/CS Act of 1998) was not 'historic rights' as was asserted by the Philippines. The Philippines provided two versions of English translation of Article 14 of China's EEZ/CS Act of 1998 from different sources. One was the official website of China's National People's Congress, which read: "The provisions in this Law shall not affect the rights that the People's Republic of China has been enjoying ever since the days of the past." 13 The other was the translation by the UN Department of Ocean Affairs and the Law of the Sea, which translated Article 14 as follows: "The provisions of this Act shall not affect the historical rights of the People's Republic of China." ${ }^{, 14}$ It is apparent that neither of the

9 Jurisdiction Hearing Tr. (Day 2), at 61-2, supra note 3. [Emphasis added]

10 See generally S. Wilske \& C. Scheidle, Seals, Stamps, and Signatures in International Arbitration Agreements, 4 Contemp. Asia Arb. J. 37-56 (2011); T. Nash, Discovering Language: A Concise Introduction to Linguistics for Chinese Students (1986).

11 Kılıç v. Turkmenistan, ICSID Case No. ARB /10/1, Decision on Article VII.2 of the Turkey-Turkmenistan Bilateral Investment Treaty, 8.5 (May 7, 2012), available at https:/www.italaw.com/sites/default/files/case-documents/ ita0932.pdf(last visited on Apr. 30, 2018).

12 Ironically, the Philippines provided an expert opinion on the meaning of the Russian terms. See "Dr Alexander Zadorozhny: Expert Opinion on the Russian term ‘историческиеправооснования' in Article 298(1)(a)(i) of the 1982 United Nations Convention on the Law of the Sea (8 March 2015)," Supplemental Written Submission of the Philippines (March 16, 2015) (Vol. IX), Annex 512, supra note 3.

13 Id. [Emphasis added]

14 Id. [Emphasis added] 
official documents translated "li shi xing quan li" into 'historic rights.' The Philippines did not provide any explanation for changing 'historical' to 'historic ${ }^{\text {, }}$ or for cutting 'rights' into "rights short of title" by omitting the exclusive right to ownership.

The apparent inconsistency between the Philippines' assertion and the evidence it presented should not have been ignored by the Tribunal, as "[ $\mathrm{t}]$ he Arbitral Tribunal shall determine the admissibility, relevance, materiality, and weight of the evidence adduced." ${ }^{, 16}$ Unfortunately, it was neglected.

\section{B. The Tribunal's Decision on "li shi xing quan li" in the Award on Jurisdiction}

How can a legal term of municipal law be interpreted in an international proceeding? The prevailing consensus is that international tribunals are "not authorized to interpret municipal law." 17 Instead, they "must follow the municipal court interpretations of municipal law." ${ }^{, 18}$ In Fisheries case, the ICJ felt obliged to "ascertain precisely what this alleged system of delimitation consists of" before considering "whether it was applied by the 1935 Decree in a manner which conformed to international law." ${ }^{, 19}$ In order to understand "the traditional Norwegian conception," the ICJ resorted to Norwegian laws, including the Royal Decree of 1812, the Decree of 1869, the Decree of 1889, the Memorandum of 1929, and the judgment delivered by the Norwegian Supreme Court in 1934 in the St. Just case, the last of which was considered the "final authority for this interpretation." 20 The ICJ was finally bound to accept those conclusions. In other words, international tribunals should resort to domestic legislations or domestic court interpretations of the legal term from the perspective of a national conception, or, at least, should pay close attention to the "the different colors of meaning." 21 Nevertheless, the Tribunal neither referred to the version on the official website of China's National People's Congress, nor did it

15 'Historical' is defined as "of or relating to or occurring in history." Here, 'historic' means 'historically significant.' See P. Nygh \& P. Butt, Butterworths Australian Legal Dictionary 404 (1997). See also C. Soanes \& S. Hawker (eds.), Compact Oxford English Dictionary of Current English 479 (3d. ed. 2005).

16 The South China Sea Arbitration (Phil. v. P.R.C.), Perm. Ct. Arb. (Case No. 2013-19), Rules of Procedure of 27 August 2013, art. 22 (7), available at https://www.pcacases.com/web/sendAttach/233 (last visited on Apr. 30, 2018).

17 P. Tisne, The ICJ and Municipal Law: The Precedential Effect of the Avena and Lagrand Decisions in U.S. Courts, 29 Fordham InT'L L. J. 870 (2005).

18 Id. at 902. See also Fisheries Case (U.K. v. Nor.), Judgment, 1951 I.C.J. Rep. 134 (Dec. 18); C. Jenks, The Prospects of International Adjudication 593 (1964).

19 Fisheries Case, $i d$.

20 Id.

21 J. Karton, Lost in Translation: International Criminal Tribunals and the Legal Implications of Interpreted Testimony, 41 Vand. J. TRansnat'L L. 23 (2008). 
notice the apparent difference between the translation in the supporting documents and that asserted by the Philippines in its Memorial. Ironically, the Tribunal did not even mention "li shi xing quan li" in both Chinese characters and Chinese pinyin in its Award on Jurisdiction of October 29, 2015.

This was a total deviation from the delicate way in which international tribunals interpret key terms. In the Dispute regarding Navigational and Related Rights case, the ICJ examined the original Spanish term, "con objetos de comercio" in the 1858 Treaty, ${ }^{22}$ its English translation used in the Cleveland Award of $1888,{ }^{23}$ its literal meaning in the context of the treaties, ${ }^{24}$ and the meanings of 'conobjetos" ${ }^{25}$ and 'comercio," respectively. The ICJ confirmed that the Spanish version of the 1858 Treaty was the only authoritative one and that it was required to return to the meaning of the Spanish terms. ${ }^{27}$ However, the Tribunal in the SCS Arbitration embraced the translation asserted by the Philippines, without making a thorough investigation of the Chinese term or the Chinese municipal laws related to it.

How did then the Tribunal link 'historic rights' with the rights China claimed? The Tribunal turned to China's Position Paper of December 7, 2014, ${ }^{28}$ aiming to establish a conceptual link. It asserted: "China divides the Philippines' Submissions among those concerned with China's historic rights, those relating to the status of certain maritime features, and those involving China's exercise of rights in the South China Sea." ${ }^{29}$ Yet, China's Position Paper of December 7, 2014, didnot mention "li shi xing quan li” or 历史性权利 at all, whereas it mentioned 'historic rights' once when citing the Philippines' submissions. ${ }^{30}$

22 Dispute regarding Navigational and Related Rights (Costa Rica v. Nicar.), Judgment, 2009 I.C.J. Rep. 213, ๆ 49 (July 13).

23 In this Arbitration, the arbitrator used the words "for the purposes of commerce" directly as a translation of the Spanish term "con objetos de comercio." However, the ICJ held that it is not convincing on the ground that "it may be supposed that this was simply because that was the English translation of the words "con objetos de comercio," which both Parties had supplied to the arbitrator, who did not wish, in his interpretation of the Treaty, to go beyond the questions which had been put before him." Id. 949.

$24 \quad I d .952$.

25 Id. $9 \uparrow$ 50-56.

26 Id. $\uparrow \uparrow$ โ $57-71$.

27 Id. 949.

28 Position Paper of the Government of the People's Republic of China on the Matter of Jurisdiction in the South China Sea Arbitration Initiated by the Republic of the Philippines of Dec. 72014 (hereinafter Position Paper), available at http://www.fmprc.gov.cn/mfa_eng/zxxx_662805/t1217147.shtml (last visited on Apr. 30, 2018).

29 The South China Sea Arbitration Award on Jurisdiction and Admissibility of 29 October 2015 before An Arbitral Tribunal Constituted under Annex VII to the UNCLOS between the Philippines and P.R. China, Perm. Ct. Arb. (Case No. 2013-19) [hereinafter Award on Jurisdiction], ๆ 134, available at https://www.pcacases.com/web/sendAttach/1506 (last visited on Apr. 30, 2018).

30 Position Paper, $\uparrow 8$. 
The Tribunal then tried to prove an imaginary link between the two official documents. ${ }^{31}$ Nevertheless, only one document (Memorandum from the Embassy of the Republic of the Philippines in Beijing to the Secretary of Foreign Affairs of the Republic of the Philippines on June 21, 2011) employed the term 'historic rights,' which reads: "China's 9-dash line claim and map is based on the 1948 declaration by the Koumingtang government ... China hopes, however, that its historic rights in the SCS be respected by the Philippines." 32

However, it is beyond doubt that this memorandum was never confirmed by China as there was an obvious typo (Kuomintang was misspelt as Koumintang), ${ }^{33}$ which is an error that would never have been ignored by their Chinese counterparts. More importantly, is it reasonable to doubt its validity or at least its competency as an important evidence produced by the Philippine Embassy during the process of the conflict with China, particularly when a unilateral arbitration against China was underway? The answer is obviously positive. The wordings - "UNCLOS also has a provision that historic rights cannot be denied"-and-China's "historic rights in the SCS be respected by the Philippines" - indicated that the 'historic rights' mentioned by China were in fact 'historic title' under Articles 15 and 298 of the UNCLOS, which was in nature a reference to sovereignty. Presumably, the Philippine Embassy might take it for granted that China's "li shi xing quan li" should be translated into 'historic rights.'

The other document the Tribunal resorted to would support that China's " $l i$ shi xing quan li" was different from the Philippines' translation. It was clear that China emphasized 'sovereignty' and "rights formed in the long course of history," which provided enough clues to the meaning of "li shi xing quan li."," "li shi' (历史) means history, while 'xing' (性) or 'xing zhi' (性质) means "bearing the character of." Accordingly, "li shi xing (zhi)" means "bearing the character of history." Hence, "li shi xing quan li" (历史性权利) refers to the rights with the character of history, which denotes that "the People's Republic of China have been enjoying right from the days of the past." Both connote a wide range of sovereignty and non-sovereignty [the]

31 Award on Jurisdiction, $₫ 160$.

32 See Memorandum from the Embassy of the Republic of the Philippines in Beijing to the Secretary of Foreign Affairs of the Republic of the Philippines, No. ZPE-064-2011-S (June 21, 2011), in Memorial (Vol. IV), at Annex 72, ๆ 8. [Emphasis added]

33 The right spelling 'Kuomintang' was used in Memorial by the Philippines, indicating that it was purely a misspelling in the document. See, e.g., Merits Hearing Tr. (Day 1), 38, $\uparrow$ ๆ $2.38 \& 4.32$, supra note 3.

34 PRC Foreign Ministry Spokesperson Jiang Yu's Regular Press Conference on September 15, 2011 (Sept. 16, 2011), available at http://www.china-embassy.org/eng/fyrth/t860126.htm (last visited on Apr. 30, 2018) See also Memorial (Vol. IV), Annex 113, at 2. 
rights that were enjoyed by China in the course of history. It is different from the concept of 'historic rights' as per the Philippine's submissions.

To conclude, the concept of 'historic rights' in the Philippines' submissions is apparently different from the concept of “li shi xing quan li” (历史性权利), but the Tribunal failed to establish a solid conceptual link between the two concepts. As a consequence, the Tribunal's decision on historic rights has no direct relationship with China's claims in the SCS.

\section{III. 'quan li' Is Not "Rights Short of Title"}

\section{A. The Philippines' Translation}

The Philippines translated 'quan li' into "rights short of title," which was logically and literally wrong. It asserted:

In respect of the historic rights of the PRC, Article 14 refers to "li shi xing quan li". The first three words, "li shi xing," mean 'historic.' The last two words, 'quan li,' are legal rights short of title. By contrast, Articles 15 and 298 of the UNCLOS speak of 'historic title', not 'historic rights.' The Chinese words for 'historic title' are, as you see before you, "li shi xing suo you quan." Again, the first three words for 'historic' are the same, "li shi xing." But the last three words, "suo you quan," are different: they mean 'title' or 'ownership.' These are the words that appear in Articles 15 and 298 of UNCLOS as the counterpart of the English words, 'historic title. ${ }^{35}$

According to the Philippines, the concepts of "quan li' (rights) and "suo you quan" (title) are mutually exclusive: "suo you quan" meant 'title' and China used 'quan li' instead of "suo you quan," so that "quan li' must mean "rights short of title." This reasoning was an absolute idea in the way of either "suo you quan" or 'quan li, without considering any possibility of inclusiveness. ${ }^{36}$

In fact, 'quan li' (权利) means a wide range of rights. The most widely used definition of right is "an interest or expectation guaranteed by law." ${ }^{, 37}$ It also refers to

35 Merits Hearing Tr. (Day 1), at $34 \& 50$.

36 Xiaolu Lei \& Minyou Yu, Legal Critique of the Historic Rights Issues in the South China Sea Arbitration Award, 2 INT'L STUD. [国际问题研究] 108 (2017).

37 A Dictionary of Modern Legal Usage 772 (2d. ed. 1995). 
"[t]he interest, claim, or ownership that one has in tangible or intangible property.",38 The UNCLOS makes detailed stipulations on, inter alia, sovereignty over the territorial sea (Article 2), "the right to establish the breadth of its territorial sea up to a limit not exceeding 12 nautical miles" (Article 3), "right of innocent passage" (Articles 8, 17, 21, 22, 23, 24 \& 52), traditional fishing rights (Article 51), "right of navigation" (Article 90), and "right to conduct marine scientific research" (Article 238). ${ }^{39}$ Conversely, “suo you quan" (所有权), or title, is a specific “ownership rights over property as recognized by a legal system," to own something, especially land or property." ${ }^{41}$

Rights include different categories of subdivisions in law, which are wellacknowledged by the domestic law in China and other States. For example, PRC Property Law provides: "The term 'real right' as mentioned in this Law refers to the exclusive right of direct control enjoyed by the holder according to law over a specific property, including ownership, usufructuary right, and real rights for security." ${ }^{, 2}$ Property rights include the title to the property and other rights affiliated to the property. In conclusion, 'quan li' (rights) is a categorical umbrella term that covers "suo you quan," rather than both being mutually exclusive. The rights (quan li) claimed by China in history included the ownership right (suo you quan) and other rights such as the right to navigation and fishing. Therefore, the Philippines' conclusion that China's employment of 'quan li' instead of "suo you quan" indicated China's claims of "legal rights short of title" was incorrect.

\section{B. The Tribunal's Decision on the Nature of "li shi xing quan li" in Its Award on Merits}

In its Award on Merits, the Tribunal accepted the Philippines' version of 'historic rights' by insisting that it was the rights "falling short of sovereignty." 43 Ironically, when the Tribunal found substantial evidence that indicated China's claims for sovereignty, ${ }^{44}$ it tried to suppress that evidence unethically by saying: "The Tribunal

38 Black's Law Dictionary 1712 (10th ed. 2014).

39 R. Churchill \& A. Lowe, The Law of the Sea 77-80, 81, 279-327, 263-4 \& 400-20 (3d. ed.1999).

40 NyGH \& ButT, supra note 15 , at 1170.

41 SoAnes \& Hawker, supra note 15, at 1087. For similar definition in other English dictionaries, see also D. DukeLow \& B. Nuse (eds.), The Dictionary of Canadian Law 1261 (2 ed. 1995); Garner, supra note 38, at 1712.

42 PRC Property Law art. 2, adopted at the 5th session of the Tenth National People's Congress on Mar. 16, 2007; entered into force on Oct. 1, 2007, available at http://www.lawinfochina.com/Display.aspx?lib=law\&Cgid=89386 (last visited on Apr. 30, 2018).

43 Award of July 12, 2016, ๆๆ 226 \& 1203(B)(2).

44 Lei \& Yu, supra note 36, at 109. 
considers that it more likely represents an error in translation or an instance of imprecise drafting, rather than a claim by China to sovereignty over the entirety of the South China Sea." ${ }^{45}$

An official Note Verbale from the PRC to the Philippines was considered "an error in translation or an instance of imprecise drafting," whereas the Philippines' internal diplomatic correspondence with a factual mistake was taken as the right translation without any doubt by the Tribunal. It was unethical and arbitrary. More importantly, the factual mistake implied by the Tribunal in this paragraph - China's claim to sovereignty over the entire SCS - was even more astonishingly wrong.

In fact, China never made such an expansive claim. ${ }^{46}$ Instead, it recognized the existence of the high seas in the SCS long before the conclusion of the UNCLOS. The declaration made by the Chinese government in 1958 cannot be clearer in that part of the SCS formed part of the high seas. ${ }^{47}$ Then, how could the Tribunal possibly imply that China made a claim over the entire SCS? Rather, it is safe to conclude that China only claimed 'quan li' (rights) over part of the SCS. This is the crucial basis for the forthcoming discussion, because the Tribunal proceeded to test whether China's conduct was compatible with "a claim that the waters of the South China Sea constitute China's territorial sea or internal waters." " Its test was to know whether China was committed to "respect both freedom of navigation and overflight" or to the "declared baselines for the territorial sea" surrounding the Xisha Islands. ${ }^{49}$ However, it should not have bothered to do so at all, as China's 1958 Declaration, which recognized the existence of the high seas in the SCS, was a sufficient proof to clear the cloud of misunderstanding.

In addition to this factual error, the Tribunal's logic reach that such conclusion was rather misleading. Does China's commitment to respect freedom of navigation and overflight, which are not provided for in the territorial sea regime under the UNCLOS, necessarily establish that China does not consider the sea areas to be equivalent to its territorial sea or internal waters? The answer is 'no' because a State may give up its rights due to various reasons. For example, the Gulf of Fonseca was recognized by the ICJ in 1992 as an historic bay jointly held in sovereignty by El Salvador, Honduras, and Nicaragua, whereas the rights of innocent passage have

45 Award of July 12, 2016, ๆ 227. [Emphasis added]

46 Yu Jia, The International Law Theory on the South China Sea Issue, 6 China Legal Scr. [中国法学] 34 (2012).

47 Declaration of the Government of the People's Republic of China on China's Territorial Sea 1958), art. 1, in Collection of the Sea Laws and Regulations of the People's Republic of China (3d. ed. 2001) [Emphasis added]. See also Memorial (Vol. V), Annex 103.

48 Award of July 12, 2016, ๆ 228.

49 Id. 1213. 
not been effected thereof, "not only for historical reasons but because of the practical necessities of a situation where those narrow Gulf waters comprise the channels used by vessels seeking access to any one of the three coastal States." ${ }^{~}$ Since the SCS is one of the vital maritime routes for vessels seeking access to its coastal States as well as to Japan and Korea, China would rather not change the status quo. Furthermore, for the peaceful settlement of maritime disputes, all State Parties concerned, "in a spirit of understanding and co-operation, shall make every effort to enter into provisional arrangements of a practical nature and, during this transitional period, not to jeopardize or hamper the reaching of the final agreement." ${ }^{, 51}$ China has committed, and shall continue to commit, to every possible provisional arrangement with bilateral agreements on joint development, joint scientific research, and a joint fishing zone, and with unilateral conduct, such as respecting freedom of navigation and overflight in the disputed areas, which shall not jeopardize China's claims in the SCS. ${ }^{52}$ Therefore, the Tribunal's conclusion was rather problematic.

\section{IV. "li shi xing" Is Not 'Historic'}

In the official documents, "li shi xing" was translated as 'historical,' not 'historic.' "Historic and historical do not have the same meaning. 'Historic' means "famous or important in history, or likely to be so in the future" (a historic occasion), whereas 'historical' chiefly means "relating to history" (historical evidence)." ${ }^{153}$ The lexical and semantic difference should not have been ignored by the Tribunal and international lawyers, ${ }^{44}$ as China's "li shi xing quan li," or 'historical rights,' refer to the rights that China has been enjoying ever since a period of time in history. The question now is about the time limits of that period in history. The establishment of maritime historic rights is inseparable from the time factor, or a time span in history, among others:

50 Case concerning Land, Island and Maritime Frontier Dispute (El Sal. v. Hond.), Judgment, 1992 I.C.J. Rep. 351, ๆף 412 \& 432 (Sept. 11). See also Lei \& Yu, supra note 36, at 108.

51 UNCLOS arts. 74(3) \& 83(3).

52 Lei \& Yu, supra note 36 , at 108. See also Jia, supra note 46, at 35.

53 SOANES \& HAWKer, supra note 15 , at 479.

54 The lexical variation and the semantic difference were ignored by some international lawyers. For example, Florian and Pierre-Marie states: “... prefer[ed] not to attach too much importance to this lexical variation, which may result from translation issues." See F. Dupuy \& P.-M. Dupuy, Legal Analysis of China's Historic Rights Claim in the South China Sea, 107 Am. J. Int'L L. 125 (2013). 
Passage of an appreciable period of time is usually necessary for building up historic rights... 'Long usage' is therefore the concise expression of the sum total of interests and relations, the existence of which creates a presumption in favour of such exceptional rights. ${ }^{55}$

Even presuming that China did claim 'historic rights' for the first time in its EEZ/CS Act of 1998, as the Philippines asserted, the Act was meant to protect the rights "that the People's Republic of China has been enjoying ever since the days of the past." Therefore, it is reasonable to deduce that China's 'long usage' had prevailed much before 1998 as historic rights are "time-honoured claims."

How long before 1998 then? Given that the Tribunal closely linked 'historic rights' with 'historic title' under the UNCLOS, the relevant provisions, namely, Article 10 (6) (historic bays), Article 15 (historic title), and Article 298 (historic bays or titles), can provide some clues. The International Law Commission ("ILC") considered the question of historic waters in 1959 and acknowledged:

There seems to be fairly general agreement that at least three factors have to be taken into consideration in determining whether a State has acquired a historic title to a maritime area. These factors are: (1) the exercise of authority over the area by the State claiming the historic right; (2) the continuity of this exercise of authority; (3) the attitude of foreign States. First, the State must exercise authority over the area in question in order to acquire a historic title to it. Secondly, such exercise of authority must have continued for a considerable time; indeed, it must have developed into a usage. $^{57}$

These criteria have been accepted by international courts and tribunals. ${ }^{58}$ Although the sufficient lapse of time for 'historic waters' is "in contrast to the situation in municipal law, where precise time-limits are prescribed," time, ${ }^{60}$ or 'time immemorial, ${ }^{61}$ to "a term of years sufficiently short to permit the

55 Y. Blum, Historic Rights, 2 Max Planck Encyclopedia of Public International Law 710-5 (R. Bernhardt ed., 1995).

56 Id.

57 See The Juridical Regime of Historic Waters, Including Historic Bays, [1962] 2 Y.B. Int'l L. Comm'n 13, U.N. Doc. A/CN.4/143. [Emphasis added]

58 Churchill \& Lowe, supra note 39, at 44. Churchill and Lowe assert that the three criteria "were implicitly accepted by the International Court of Justice" in the Gulf of Fonseca Case.

59 See supra note 57 , at 11.

60 The ICJ referred to as "ancient and peaceful usage." See Fisheries Case, supra note 18, at 142.

61 See supra note 57 , at 15 . 
States who achieved independence in the decades following World War II."62 It should be considered that the Yaoundé Declaration (1972) rejected the notion that a claim on historic bays could not be sustained by a newly independent African State in the postwar period ${ }^{63}$ and the UNCLOS recognized historic titles and bays in relevant articles. In this regards, the time duration may extend to 1982 when the UNCLOS was concluded. As far as the time-limits are concerned, therefore, the word 'historical' implies a time span from ancient time to $1982 .{ }^{64}$ As a consequence, China's "li shi xing quan li," or 'historical rights,' refers to the privilege that had prevailed from ancient times to 1982, which became a fundamental issue in the SCS Arbitration.

\section{A. Critical Date for the Dispute over 'Historic Rights'}

The 'critical date' may be defined as "the point of time falling at the end of a period within which the material facts of a dispute are said to have occurred." ${ }^{65}$ It has been invoked extensively by the ICJ. "66 "The key to determining critical date is whether the dispute has crystallized, or, in other words, whether the Parties have officially put forward competing claims in an unequivocal manner over territorial sovereignty or maritime interests." ${ }^{\circ 7}$

How can the critical date for the dispute over 'historic right' be calculated in this case? According to the Philippines, "[t]he first official Chinese reference to such 'historic rights' came in 1998." ${ }^{\circ 8}$ Therefore, it is logical that the 'historic' rights must have existed before 1998, as 'historic' relates to events that happened in history. However, the Philippines also asserted that China "first claimed the existence of such rights (historic rights) on 7th May 2009." ${ }^{\circ 9}$ This may be true as a dispute may not

62 S. Kaye, The South Australian Historic Bays: An Assessment, 17 Adel. L. Rev. 272 (1995).

63 See African States: Conclusions of the African States Regional Seminar on the Law of the Sea (June 30, 1972), circulated as a Document of the United Nations General Assembly Committee on the Peaceful Uses of the Sea-Bed and Ocean Floor beyond the Limits of National Jurisdiction 11, U.N. Doc. A/AC.138/79, republished at 12(1) I.LM. 210-3 (1973), available at http://www.jstor.org/stable/20691053 (last visited on Apr. 30, 2018).

64 Chinese scholars and policymakers held that China's li shi xing quan li in the SCS existed long before the enactment of the UNCLOS. See Jian Zhang, China's South China Sea Policy: Evolution, Claims and Challenges, in The South China Sea Maritime Dispute: Political, Legal and Regional Perspectives 72 (L. Buszynski \& C. Roberts eds., 2015).

65 L. Goldie, The Critical Date, 12 InT'L \& ComP. L. Q. 1251 (1963).

66 See Sovereignty over Pulau Ligitan and Pulau Sipadan (Indon. v. Malay.), Judgment, 2002 I.C.J. 625 , 1931 \& 135 (Dec. 17); Sovereignty over Pedra Branca and Pulau Baru Puteh, Middle Rocks and South Ledge (Malay. v. Sing.), Judgment, 2008 I.C.J. 28, ๆๆ 33 \& 34 (May 23); Territorial and Maritime Dispute between Nicaragua and Honduras in the Caribbean Sea (Nicar. v. Hond.), Judgment, 2007 I.C.J. 699, 123 (Oct. 8).

67 Ran Guo, Legal Basis of China's Claim over the Huangyan Island, 6 J. EAST AsIA \& InT'L L. 548 (2013).

68 Merits Hearing Tr. (Day 1), at 29. See also Memorial, 4.28.

69 Merits Hearing Tr. (Day 1), at 77. 
crystalize until the other Party officially puts forward competing claims. Then, "when China did make clear in May 2009 that it claims historic rights in the maritime areas within the 'nine-dash line,' the Philippines submits that this was promptly objected to by the other littoral States of the South China Sea."70 Therefore, May 7, 2009 could be safely regarded as the 'critical date' for the dispute over 'historic rights,' even if the Philippines' points of view were given full credit.

"The extent of the rights asserted within the 'nine-dash line' only became clear with China's Notes Verbales of May 2009. Since then, China's claims have been clearly objected to by other States." ${ }^{, 71}$ The Tribunal's wording indicated that the dispute over 'historic rights' was crystallized on May 7, 2009. However, this was rather inconsistent with its Award on Merits. The Tribunal made "reference to the Parties' diplomatic correspondence between 7th May 2009 and 14th April 2011" as follows:

In the Tribunal's view, a dispute is readily apparent in the text and context of this exchange (China's Note of 14 April 2011): from the map depicting a seemingly expansive claim to maritime entitlements, to the Philippines' argument that maritime entitlements are to be derived from "geological features" and based solely on the Convention, to China's invocation of "abundant historical and legal evidence" and rejection of the contents of the Philippines' Note as "totally unacceptable.,"72

Apparently, the Tribunal also took April 14, 2011, as the 'critical date' for the dispute. In conclusion, the Tribunal might have considered the period "from May 7, 2009 to April 14, 2011," as the critical period for the dispute over China's "expansive claim to maritime entitlements."

\section{B. Critical Date Test regarding the Evidence for 'Historic Rights'}

The critical date is the "determining moment at which it might be inferred that the rights of the parties have crystallized so that acts after that date cannot alter the legal position." When the dispute achieved its critical date, "the respective claims of the Parties therefore [found] themselves 'legally neutralized,' and that, for this reason, their subsequent statement or actions are not relevant to the present proceedings."

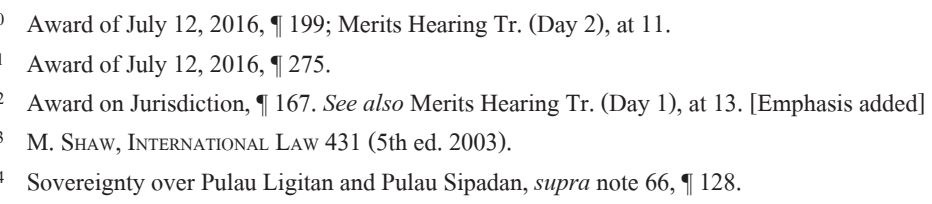


Any subsequent attempts to bolster their claims would be inconsequential to the legal analysis; ${ }^{75}$ and any acts after the critical date shall not be considered by international tribunals "unless such acts are a normal continuation of prior acts and are not undertaken for the purpose of improving the legal position of the Party which relies on them." those acts or evidence that should be considered by international tribunals from those that should not. ${ }^{77}$

Regarding the dispute over China's claim to 'historic rights,' only those acts undertaken before May 7, 2009 should be given evidentiary value in determining the nature of 'historic rights.' No act considered by any Party after the critical date shall make any difference. The Tribunal resorted to three instances to analyze the nature of China's 'historic rights' in the SCS: (1) the notice of open blocks for petroleum exploration, issued by the China National Offshore Oil Corporation ("CNOOC") in June 2012; (2) China's declaration of a "Summer Ban on Marine Fishing in the South China Sea Maritime Space” in May 2012; and (3) China's Vice Foreign Minister's statement in October 2015 on China's respect for freedom of navigation. ${ }^{78}$ None of these three instances, which happened in 2012, 2012, and 2015, respectively, should have been given any probative value by the Tribunal in determining 'historic rights,' as all of them happened after the critical date - either 2009, according to the Philippines, or 2009-11, according to the Tribunal. Therefore, these instances were not competent to indicate the nature of "China's claim to historic rights" at all.

\section{V. "li shi xing quan li" Is Not "Historic Rights Short of Title"!}

\section{A. China's "li shixingquan li" and Pre-Arbitration 'Historic Rights'}

In a memorandum prepared for the first UN Conference on the Law of the Sea

75 M. Byers, International Law and the Arctic 13 (2013). See R. Jennings \& A. Watts, Oppenheim's International LAw 711 (9th ed. 2008).

76 Supra note $66,9135$.

77 Guo, supra note 67 , at 550.

78 Award of July 12, 2016, $\uparrow$ ๆ 207-214. Although the Tribunal employed the phrase "China's repeated invocation of rights 'formed in the long historical course," instead of 'historic rights,' in the beginning of this section ( $\mid 207)$, it indeed referred to 'historic rights' as it held that "China has, for instance, repeatedly claimed 'historic rights' or rights 'formed in history' in the South China Sea." See Award on Jurisdiction, at 160. 
in 1958, Norway explicitly claimed with respect to the Lopphavet basin that historic rights included 'historic bays,' 'historic waters,' and 'historic rights. ${ }^{, 79}$ This comprehensive concept of 'historic rights' was confirmed by the ILC's study on the juridical regime of historic waters in $1962 .{ }^{80}$ Furthermore, it was once again connoted as specific consensus among international lawyers ${ }^{81}$ before the SCS Arbitration as follows:

The concept originated in the State practice at the end of the 19th century in order to justify the survival of territorial sovereignty over certain bays and gulfs ("historic bays") or other arms of the sea ("historic waters") despite the on-going attempt to develop restrictive general rules on the determination of the baselines of the territorial sea. Later, however, a tendency emerged in the legal literature to develop a general category of historic rights, comprehensive of all other rights acquired by virtue of a similar historic title, such as sovereignty over land territory acquired by a process of "consolidation by historic title," historic rights falling short of full territorial sovereignty (i.e., rights of passage or rights relating to fisheries), or even historic rights relating to the manner of delimitating boundaries, especially maritime boundaries. ${ }^{82}$

International lawyers well acknowledged that it includes: (1) exclusive historic rights, which are sovereignty over land territory and certain bays and waters; and (2) nonexclusive historic rights, which are short of full territorial sovereignty, such as fishing and navigation. "International courts and tribunals have accepted the preservation of historic rights in parallel to the jurisdictional regime established by the UNCLOS." ${ }^{84}$ In the Tunisia/Libya case, the ICJ declared: "Historic titles must enjoy respect and be reserved as they have always been by long usage." ${ }^{, 85}$ In other

79 See Historic Bays: Memorandum by the Secretariat of the United Nations, U.N. Doc. A/CONF.13/1 (1958), Official Records of the United Nations Conference on the Law of the Sea (Vol. I) (Preparatory Documents), at 2 \& 7, available at http://legal.un.org/diplomaticconferences/1958_los/voll.shtml (last visited on Apr. 30, 2018).

80 Supra note 57.

81 C. Symmons, Historic Waters and Historic Rights in the South China Sea: A Critical Appraisal, in UN Convention on the Law of the Sea And the South China Sea 191-238 (S. Wu \& M. Valencia eds., 2015). See also Keyuan Zou, Historic Rights in International Law and in China's Practice, 32 Ocean Dev. \& InT'L L. 149-68 (2001); Blum, supra note 55; Jia, supra note 46, at 33.

82 A. Gioia, Historic Titles, 4 Max Planck Encyclopedia of Public International Law 815 (R. Wolfrum ed., 2013).

83 According to Kopela, e.g., historic rights include two types: (1) Historic titles entailing sovereignty (historic waters) and (2) Historic rights short of sovereignty. The latter takes two different and distinct forms: "historic rights short of sovereignty, which have a quasi-territorial or zonal impact beyond the territorial sea; and nonexclusive historic rights (mainly related to fishing rights)." See S. Kopela, Historic Titles and Historic Rights in the Law of the Sea in the Light of the South China Sea Arbitration, 48 OCEAn Dev. \& INT'L L. 187-96 (2017).

84 Id. at 186.

85 Continental Shelf (Tunis. v. Libya), Judgment, 1982 I.C.J. Rep. 73, 100 (Feb. 24). 
words, as far as historic rights and titles have created a special regime related to the specific historic circumstances, international courts and tribunals cannot phase out historic claims as a whole. Instead, they must examine the history of each individual situation by considering the UNCLOS. ${ }^{86}$

The Tribunal was aware of the connotation of such concepts as 'historic rights,' 'historic bays,' 'historic waters,' and 'historic title. ${ }^{, 87}$ Nevertheless, it phased out exclusive historic rights, or territorial sovereignty, over the Islands and its territorial sea, from the composition of the pre-Arbitration definition of 'historic rights,' although exclusive historic rights (historic waters) "are merely one form of historic right and the process is the same for claims to rights short of sovereignty." ${ }^{88}$ Even this narrowly limited 'historic rights' has three types of specific connotations in practice, namely, (1) "rights of passage"; (2) "rights relating to fisheries;" and (3) "rights relating to the manner of delimitating boundaries, especially maritime boundaries," 89 which is supported by Chinese international lawyers ${ }^{90}$ as well as international judicial decisions. ${ }^{91}$ It is hard to claim historic rights over other issues such as nonliving resources on the seabed, in history.

In a sense, the development from a narrow concept of 'historic bays' or 'historic waters' at the end of the nineteenth century to a general category of historic rights in the mid-twentieth century came along with the course that China consolidated its "li shi xing quan li" in the SCS, which was confirmed in its EEZ/CS Act of 1998. To this extent, China's "li shi xing quan $l i$ " in the SCS is as good as the general category of historic rights, which, comprising both historic title and historic sovereign right, denotes both the source and the evidence of right over land or maritime territory acquired by a state through a process of historical consolidation. ${ }^{2}$ China did not

86 Kopela, supra note 83, at 186.

87 Award of July 12, 2016, ๆ 225.

88 Id. $\uparrow$ 265. Yee argued: 'Often 'historic title' and 'historic rights'- a broader term - are used interchangeably, and thus historic title may be interpreted to cover both claims regarding sovereignty rights - territorial titles - and claims relating to non-sovereignty rights or non-territorial rights." See Sienho Yee, The South China Sea Arbitration (The Philippines v China): Potential Jurisdictional Obstacles or Objections, 13 CHINESE J. INT'L L. 730 (2014).

89 GIoIA, supra note 82

90 Minyou Yu \& Xiaolu Lei, Rebuttal of the USA's Accusation of China's Interference of Freedom of Navigation in the South China Sea [评美国指责中国在南海的权利主张妨碍航行自由的无理性], 9 JIANGXI SoCIAL SCI. [江西社会科学] 13-9 (2011). See also Ran Guo, A Study on China's Historic Rights over the Waters within 'the U-shaped Line' of the South China Sea, 21(12) PACIFIC J. 40-9 (2013).

91 See, e.g., Case concerning Right of Passage over Indian Territory (Port. v. India), Judgment, 1960 I.C.J. Rep. 6, ๆ 39 (Apr. 12); Delimitation of the Maritime Boundary in the Gulf of Maine Area (Canada v. U.S.), Judgment, 1984 I.C.J. Rep. 246, ๆๆ 234-236 (Oct. 12); Maritime Delimitation and Territorial Questions between Qatar and Bahrain (Qatar v. Bahr.), Judgment, 2001 I.C.J. 40, 9236 (Mar. 16).

92 GioIA, supra note 82. See also Guo, supra note 90. 
translate "li shi xing quan li" into 'historic rights' only because the latter was not a legal term with equivalent semantic clarity and certainty as the former. The historical consolidation process indicates that it is the historic title over these qundao (Islands) and their territorial sea on which China has effectively and continuingly exercised governmental authority. Meanwhile, the historic sovereign rights, mainly fishing and navigation, due to a lack of clear continuity and exclusiveness, play a rather limited role in China's claims over the waters. ${ }^{93}$

It is China's inalienable right to claim the Nansha Islands' territorial sea, contiguous zone, and EEZ/CS under the UNCLOS. ${ }^{94}$ As the sovereignty over the Nansha Islands was beyond the Tribunal's jurisdiction, ${ }^{95}$ the limit of its maximum maritime entitlements was a point at issue for the SCS Arbitration.

\section{B. "li shi xing quan li": China's Maximum Maritime Entitlements in the SCS}

In its Award on Merits, the Tribunal distinguished two types of rights claimed by China: (1) the rights in areas within the maximum entitlements that could be claimed under the UNCLOS; and (2) those in areas beyond. ${ }^{96}$ As " $[\mathrm{m}] \mathrm{uch}$ of the area encompassed by the 'nine-dash line,' however, would also fall within a claim to an exclusive economic zone or continental shelf drawn from the various features of the Spratly Islands," ${ }^{97}$ the maximum entitlements of the Nansha Islands under the UNCLOS became the prerequisite for the discussion on whether China's claimed rights are in areas either within or beyond the maximum entitlements, and therefore worth a thorough analysis. Presumably, the limit of the maximum entitlements under the UNCLOS can be measured from either the Nansha Islands as a single unit, or individual islands in the Nansha Islands.

\section{China's Maximum Entitlements from the Nansha Islands as a Single Unit}

The Tribunal did not support China's entitlement to maritime zones as a single unit because it did not support the application of archipelagic or straight baselines

93 Guo, supra note 90.

94 Statement of the Government of the People's Republic of China on China's Territorial Sovereignty and Maritime Rights and Interests in the South China Sea (July 12, 2016), pt. III, available at http://www.fmprc.gov.cn/mfa_eng/ zxxx_662805/t1379493.shtml (last visited on Apr. 30, 2018).

95 It was not a dispute concerning sovereignty over such features, or a dispute concerning sea boundary delimitation. See Award on Jurisdiction, \153.

96 Award of July 12, 2016, 207.

97 Id. 
to the Nansha Islands. ${ }^{98}$ While the Tribunal's 'archipelagic baseline' argument was fictitious as China had never proposed to apply the archipelagic baseline to the Nansha Islands. In the meantime, its 'straight baseline' argument was rather an assertion than an argument, as the Tribunal "exclude[d] the possibility of employing straight baselines in other circumstances," although it was fully aware that "the Convention does not expressly preclude the use of straight baselines in other circumstances" and the state practice "employing straight baselines with respect to offshore archipelagos." 100

Its misunderstanding is rooted in the Chinese term, nansha qundao (南沙群岛， Nansha Islands). Although China repeatedly asserted its sovereignty over nansha qundao in its domestic laws, public statements, diplomatic correspondence, and other official documents, the Tribunal did not try to consider the Chinese term at all and regarded these evidence as 'irrelevant." ${ }^{101}$ The translation of nansha qundao into the Spratly Islands has also neglected the core meaning of China's claims in the SCS. The Chinese term nansha qundao connotes the sovereignty of the islands unity, including its islands, features, internal waters, and territorial sea, all of which have been clear and consistent with China's practice and claims. ${ }^{102}$ Moreover, it has been acknowledged by the international society, for example, Vietnam, one of the important Parties to the SCS dispute.

The Sino-Vietnam consensus on the term nansha qundao is relevant to the SCS Arbitration, because the Tribunal asserted: "CNOOC's 2012 notice ... assist[ed] in understanding the nature of China's claims within the 'nine-dash line'." 103 The Tribunal wanted to prove that "[ $t$ ]he western portions of at least one of these blocks (Block BS16) lie beyond 200 nautical miles from any feature in the South China Sea claimed by China, and beyond any possible extended continental shelf." ${ }^{104}$ However, the Tribunal was not eligible to rule on CNOOC's notice unless it had taken into full consideration of Vietnam's related claims and conduct, and international agreements, as the UNCLOS should not alter the rights and obligations of State Parties that arise from other bilateral or multilateral agreements compatible with it. $^{105}$

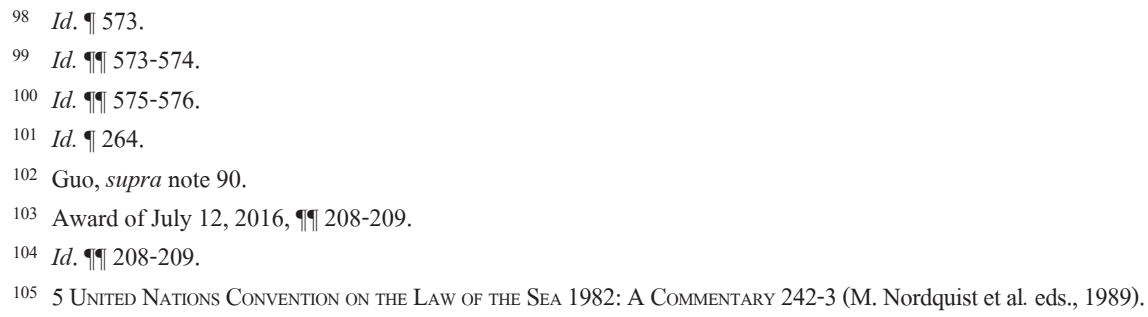


More importantly, both China and Vietnam, through their respective domestic legislations, have agreed from the very beginning that nansha qundao as a unit can possess its territorial sea and EEZ/CS. ${ }^{106}$ The Tribunal should have at least considered such consensus between China and Vietnam. Unfortunately, this was ignored in the end by the Tribunal.

Besides the Sino-Vietnam consensus, the Tribunal also failed to consider relevant international treaties, including the Treaty of Peace with Japan (1951) ${ }^{107}$ and the Treaty of Peace between the Republic of China and Japan (1952), ${ }^{108}$ which recognized that the Spratly Islands was and could be the subject matter of territorial title, as possible bases to regard the Spratly Islands as a single unit. ${ }^{109}$ In other words, besides Vietnam, all the 48 parties to the 1951 Peace Treaties, including the Philippines, Indonesia, the US, the UK, and Japan, "knew and understood the Spratly Islands to mean sinnan gunto, an area in the South China Sea whose limits were well defined and the principal components of which were identified ... the Spratly Islands is in international law a unit ... such that the fate of the principal part may involve the rest." 110 From this perspective, the SCS Arbitration left open the question whether nansha qundao was capable of generating its EEZ/CS as a single unit. If generating its EEZ/CS, China's maximum entitlements should be measured from the baselines of the territorial sea of nansha qundao.

\section{China's Maximum Entitlements from Individual Islands in the Nansha Islands}

The Tribunal concluded that "none of the high-tide features in the Spratly Islands, in their natural condition, are capable of sustaining human habitation or economic life of their own within the meaning of Art. 121(3) of the Convention," and none generate entitlements to an EEZ/CS. ${ }^{111}$ However, it is apparently problematic for the Tribunal to rule out all 148 features ${ }^{112}$ by examining only 6 of them, ${ }^{113}$ Further, given

\footnotetext{
106 Ran Guo, Sino-Vietnam Dispute over Hydrocarbon Resources Exploration in Nansha Waters after the South China Sea Arbitration, 47 Hong Kong L. J. 963-4 (2017).

107 Treaty of Peace with Japan (1951), 136 U.N.T.S. 45, art. 2(f).

108 Treaty of Peace between the Republic of China and Japan (1952), 138 U.N.T.S. 38, art. 2.

109 M. Loja, The Spratly Islands as a Single Unit under International Law: A Commentary on the Final Award in Philippines/China Arbitration, 47 OcEan Dev. \& Int'L L. 319 (2016).

110 Id. at 318 .

111 Award of July 12, 2016, ๆ 1203 (B)(7).

112 D. Hancox \& V. Prescott, A Geographical Description of the Spratly Island and an Account of Hydrographic Surveys amongst Those Islands, 1(6) Maritime Briefing 3 (1995). See also D. Dzurek, The Spratly Island Dispute: Who's on First?, 2(1) Maritime Briefing 1 (1996). Dzurek holds that there are 170 features in Nansha.

113 The six large islands include Itu Aba (Taiping Dao), Thitu (Zhongye Dao), West York Island (Gigue Dao), Spratly Island (Nanwei Dao), North-East Cay (Beizi Dao), and South-West Cay (Nanzi Dao). See Award of July 12, 2016, $\mathbf{q \uparrow}$
} 
that the contradictory expert witness, Professor Clive Schofield for the Philippines in the SCS arbitration delivered his opinions without a thorough examination of all relevant 'islands,' the Tribunal's conclusion - none of the features in nansha qundao was an 'island' - would be rather doubtful as well. ${ }^{114}$ Therefore, neither the evidence nor the logic was convincing for its conclusion, ${ }^{115}$ thereby leaving open a contrario sensu on whether there were fully entitled islands in nansha qundao, which were capable of generating EEZ/CS.

China's maximum maritime entitlements in the SCS, from either the Nansha Islands as a single unit or its individual islands, were not fully settled down because the Tribunal's conclusion was based on rather unconvincing logic with contradictory evidence. In this regard, China's activities since 1996 when it ratified the UNCLOS may be merely provisional arrangements to safeguard its maritime interests before the final delimitation in the SCS. Actually, China's position would reverse the Tribunal's decision. Therefore, the Tribunal should have adjudged the legality of China's claims in the SCS with a thorough investigation of these two possibilities.

\section{Conclusion}

"Historic rights, which are established on the basis of a particularized regime and can thus be regarded as lex specialis, cannot be superseded by a general treaty without explicit reference to them." "116 The Philippines intentionally translated the Chinese legal term, "li shi xing quan li" into "historic rights short of title" regardless of the official English translation provided by the Chinese government and preserved by international organizations. The inconsistency should not have been overlooked by the Tribunal.

The Chinese term 'quan li' connotes a categorical meaning covering sovereignty and non-sovereign rights. Meanwhile, "rights short of title" is an English translation with much narrower implication than the Chinese term, 'quan li.' The Chinese term "li shi xing" does not mean 'historic,' but 'historical.' It relates to claims and conduct

401-406.

114 Guo, supra note 106, at 963-4.

115 For details on Award on Jurisdiction, see Tiantian He, Commentary on Award on Jurisdiction and Admissibility of the Philippines-Instituted Arbitration under Annex VII to the UNCLOS: A Discussion on Fact-Finding and Evidence, 2 Chinese J. Global Governance 96-128 (2016). See also Yee, supra note 88.

116 Kopela, supra note 83, at 184. 
that have been made by China from ancient times up to 1982. The differentiation of terms is significant because the critical date, either 1982 for the dispute over "li shi xing quan li," or 2009-2011 for the dispute over 'historic rights,' should have helped the Tribunal to consider the competency of the evidence before it: accepting those formed before the critical date and discarding those after the critical date.

China's "li shi xing quan li" in the SCS has evolved with the general category of historic rights that was well-acknowledged by international lawyers as an umbrella concept connoting both exclusive historic title and non-exclusive historic sovereign rights. It included China's exclusive sovereignty (historic title) over nansha qundao in the SCS and its non-exclusive sovereign rights (rights short of title, such as fishing and navigation) in part of SCS. ${ }^{117}$ China reiterated its claim over the general category of historic rights in the SCS ${ }^{118}$ after the Arbitration to protest the "null and void" awards of the Tribunal. ${ }^{119}$

China's maritime entitlements under the UNCLOS may start from either nansha qundao as a single unit, as China claimed, following international agreements on the legal status of nansha qundao, or individual islands of nansha qundao, as the Tribunal insisted. As neither was appropriately addressed by the Tribunal, the limit of China's maximum entitlements in the SCS is thus leaving open.

As of today, one cannot exactly say what China's maximum entitlements exactly are. However, there are reasonable doubts, at least, on the Tribunal's conclusion about "the geographic and substantive limits of China's maritime entitlements" 120 and its decision on the Philippines' Submissions 1 \& 2. In other words, if China claimed especially historic rights to the living and non-living resources within the 'nine-dash line,' within the limits of China's maritime zones as provided for by the UNCLOS, China's claims would be compatible with the Convention and thus legitimate. The Tribunal should have made a thorough investigation of the Chinese connotation as well as corresponding conduct concerning the term "li shi xing quan li," which was totally different from the Tribunal's version of 'historic rights.'

117 Lei \& Yu, supra note 36, at 119.

118 Supra note 94. The Statement confirmed that li shi xing quan li was a comprehensive concept that connoted both exclusive historic title and non-exclusive historic sovereign rights. See Lei \& Yu, supra note 36, at 119.

119 See Position Paper, supra note 28. See also Statement of the Government of China, supra note 94.

120 Award of July 12, 2016, ๆ 278. 